\title{
Testing Todd: family types and development
}

\author{
Jerg Gutmann ${ }^{1,2}$ (D) and Stefan Voigt ${ }^{1,2 *}$ (B) \\ ${ }^{1}$ Institute of Law and Economics, University of Hamburg, Johnsallee 35, D-20148 Hamburg, Germany and ${ }^{2}$ CESifo, Munich, \\ Germany \\ *Corresponding author. Email: stefan.voigt@uni-hamburg.de
}

(Received 3 May 2020; revised 22 February 2021; accepted 22 February 2021; first published online 23 March 2021)

\begin{abstract}
Many years ago, Emmanuel Todd came up with a classification of family types and argued that the historically prevalent family types in a society have important consequences for its economic, political, and social development. Here, we evaluate Todd's most important predictions empirically. Relying on a parsimonious model with exogenous covariates, we find mixed results. On the one hand, authoritarian family types are, in stark contrast to Todd's predictions, associated with increased levels of the rule of law and innovation. On the other hand, and in line with Todd's expectations, communitarian family types are linked to racism, low levels of the rule of law, and late industrialization. Countries in which endogamy is frequently practiced also display an expectedly high level of state fragility and weak civil society organizations.
\end{abstract}

Key words: Constitutional structure; economic development; family structures; family systems; family types; ideology; state formation

JEL Codes: D10; H11; J12; K36; N30; O17; Z12

\section{Introduction}

Over the last decade, economists have become interested in identifying the 'deep causes' of economic development - instead of only its proximate causes, such as investment in physical and human capital. Various aspects of geography, including the suitability of soil for planting specific crops, ruggedness of the terrain, being landlocked, climate, and the intensity of rainfall have featured prominently in this literature (see Spolaore and Wacziarg, 2013 for a survey). An important debate ensued on whether geography has a direct influence on development or whether its effect on development was primarily mediated via institutions (see, e.g. Acemoglu et al., 2001; Rodrik et al., 2004; Sachs, 2003; Voigt, 2013). Others have examined the role of cultural and genetic differences within and between populations as causes of economic development (Ashraf and Galor, 2013; Gorodnichenko and Roland, 2017; Spolaore and Wacziarg, 2009). More recent research has extended the scope of analysis to the deep causes of political and legal development (e.g. Davis and Abdurazokzoda, 2016; Davis and Williamson, 2019, 2020; Gutmann and Voigt, 2018, 2020).

A number of anthropologists argue that family types - often also referred to as family structures or family systems - are an important determinant of development, for example in terms of fertility and education levels. Among them is Emmanuel Todd (1985) who claims not only that family structures are extremely stable over time, but also that they determine: (1) ideological convictions, (2) state formation, (3) constitutional structure, and (4) post-constitutional outcomes of societies. If family types are as important as Todd claims, economists interested in identifying possible transmission channels from geographic conditions to economic and political development would do better to take them into account. Our goal here is, therefore, to empirically evaluate Todd's most important theoretical predictions.

Todd (1985) bases his typology of family systems on two core values of the French revolution, liberté and égalité. Drawing on the seminal work of Le Play (1895), he claims that liberty is determined by the

(c) Millennium Economics Ltd 2021. This is an Open Access article, distributed under the terms of the Creative Commons Attribution licence (http://creativecommons.org/licenses/by/4.0/), which permits unrestricted re-use, distribution, and reproduction in any medium, provided the original work is properly cited. 
Table 1. Schematic representation of family types

\begin{tabular}{|c|c|c|c|c|}
\hline & & \multicolumn{3}{|l|}{ Liberty } \\
\hline & & Low: married son stay & parents & $\begin{array}{l}\text { High: married son } \\
\text { moves out }\end{array}$ \\
\hline \multirow[t]{2}{*}{ Equality } & $\begin{array}{l}\text { Low: unequal } \\
\text { treatment of } \\
\text { brothers }\end{array}$ & $\begin{array}{l}\text { Authoritarian (e.g. Nor } \\
\text { Ireland) }\end{array}$ & Sweden, Germany, & $\begin{array}{l}\text { Absolute nuclear } \\
\text { (e.g. England, } \\
\text { Canada, USA) }\end{array}$ \\
\hline & $\begin{array}{l}\text { High: equal } \\
\text { treatment of } \\
\text { brothers }\end{array}$ & $\begin{array}{l}\text { Endogamous } \\
\text { community (e.g. } \\
\text { Pakistan, Morocco) }\end{array}$ & $\begin{array}{l}\text { Exogamous } \\
\text { community (e.g. } \\
\text { Russia, Mongolia, } \\
\text { China) }\end{array}$ & $\begin{array}{l}\text { Egalitarian nuclear } \\
\text { (e.g. Spain, Italy, } \\
\text { Poland) }\end{array}$ \\
\hline
\end{tabular}

relationship between fathers and their sons, whereas equality is determined by inheritance rules. If sons still live under one roof with their parents, even after getting married, their liberty is curtailed; whereas, if sons establish their own household, they enjoy considerably more freedom. Regarding inheritance, Todd (1985) argues that if all children receive the same share of the father's wealth, this fosters equality in society at large. If, in contrast, rules prevail that envision the indivisibility of the estate, this may facilitate inequality in society. Combining these two dimensions allows Todd to distinguish four family types (see Table 1). It should already be noted here that we are not able to distinguish between countries of the absolute and the egalitarian nuclear family type in our empirical analysis, as the dataset by Rijpma and Carmichael (2016) identifies only a handful of countries that are dominated by the absolute nuclear family type. Thus, we combine the two categories into one. Fortunately, Todd (1985) himself emphasizes the similarities between the absolute and the egalitarian nuclear family types, describing them in a single chapter under the title 'The Two Forms of Individualism'.

Todd (1985) adds a third dimension to this classification, asking whether consanguineous marriages are socially accepted or even desired. He then proposes to split the category 'community' into 'exogamous community' types and 'endogamous community' types. In exogamous communities, marriage within the family is not accepted. In endogamous communities, marriage between cousins is accepted and often even encouraged. Both types share the equal treatment of brothers in inheritance rules, as well as the trait that sons do not move out of their parents' household after marriage. According to Todd, a belt of countries ranging from Pakistan in the East to Morocco in the West is characterized by this family type. ${ }^{1}$

Since most economists at the time were not interested in culture and family organization, Todd's claims were largely ignored in their discipline. ${ }^{2}$ Only recently, empirical economists have become interested in his work. In their analysis of the relevance of family characteristics for income per capita, institutional quality, and political participation, Alesina and Giuliano $(2011,2014)$ do not consider historical family types, but only contemporary 'family ties', ${ }^{3}$ i.e. the number of generations living under one roof as of today or some years ago. However, Alesina and Giuliano (2011) state explicitly

\footnotetext{
${ }^{1}$ Todd introduces a third type of the community family that he calls the 'asymmetrical community type'. In this type, marriages between parallel cousins are taboo, whereas cross-cousin marriages are encouraged (a parallel cousin is the paternal uncle's or the maternal aunt's child, whereas a cross-cousin is the maternal uncle's or the paternal aunt's child). This family type exists, for example, in southern parts of India. We subsume this type under the endogamous community category, because within-family marriage is accepted.

${ }^{2}$ Obviously, research in family economics has contributed much to our understanding of decision-making within households (Becker, 1981). However, family economics is almost exclusively based on neoclassical economics, sometimes complemented with behavioral economics assumptions, such as altruism. Culture and institutions play only a marginal role in this strand of literature.

${ }^{3}$ It is essential for understanding our arguments and the value added of this study to understand the fundamental difference between family ties and family types. Although the former refer to the typical organization of a family (specifically the propensity of adult children to still live with their parents), the latter describe historical informal (and maybe also formal) institutions that govern the organization of families and are thought to be highly persistent over time.
} 
that Todd's argument for some family structures being more compatible with certain types of political organization than others merits further investigation. Researchers have since taken on this task.

The relevant literature can be divided into (1) studies interested in the determinants of economic development; (2) studies inquiring into the causes of institutional quality broadly conceived; and (3) studies focusing on more specific political outcomes, such as voter turnout. Since only a few empirical studies analyze the effects of family types, we also survey studies on the effects of inheritance practices, that is, the effects of one defining dimension in Todd's typology. ${ }^{4}$

De la Croix and Perrin (2018) explain changes in fertility rates and educational attainment - two aspects of economic development - in France over the centuries and find that family structures add substantial explanatory power to their empirical models. Ellul et al. (2010) find that stricter regulation of inheritance practices is associated with lower investment into family firms. Duranton et al. (2009) were the first to comprehensively evaluate the relevance of family systems for socio-economic characteristics of European regions, such as household size, educational attainment, social capital, labor force participation, the share of the workforce employed in manufacturing, wealth, and income inequality. In their analysis of NUTS-2 regions ${ }^{5}$ in 16 Western European countries, Duranton et al. observe a dividing line between regions characterized by the absolute nuclear family and those characterized by any other family type. The former exhibits a comparatively smaller household size, more education, higher employment rates and social capital, a larger service sector, and a more dynamic economy. In spite of some similarities, our study is clearly different from that of Duranton et al. (2009) in that our sample has a global and far broader country coverage and we are interested in more than just the economic effects of family types.

Dilli (2016) was the first study to link family systems to institutional quality and finds that countries characterized by a nuclear household structure are more democratic. Broms and Kokkonen (2019) argue that inheritance regimes favoring a single heir are conducive to the development of both private property rights and social trust, which, in turn, is conducive to high-quality institutions. They find support for trust being a transmission channel from non-egalitarian inheritance rules to contemporaneous institutional quality. Schulz (2020) studies the effects of regulating consanguineous marriage and finds that countries in which this practice is prohibited display significantly higher democracy scores, higher rates of political participation, and higher institutional quality than other countries.

Bonoldi et al. (2020) find that in South Tyrol (a region in Northern Italy that is influenced by both Italian and Germanic tradition and, thus, by competing inheritance rules), villages with an inheritance rule similar to primogeniture display higher voter turnout. Galasso and Profeta (2018) analyze the timing of the introduction of state-run pension systems and their generosity vis-à-vis pensioners. They theorize that citizens in countries with egalitarian inheritance rules prefer more generous pension systems, which is supported by the data. Galasso and Profeta also consider the other two dimensions of Todd's family structures, cohabitation and endogamy, and find that they are not related to differences across countries in pension system design. Galasso and Profeta's (2018) finding that even the preferences of second-generation immigrants to the USA can be explained by the inheritance rules in their parents' home country is also relevant here. This is consistent with Todd's argument that family types are, like culture in general, highly persistent and have long-lasting consequences. Further corroborating evidence for the persistence of family structures and values is provided, for example, by Bertrand and Schoar (2006), Enke (2019), and Reher (1998). ${ }^{6}$

\footnotetext{
${ }^{4}$ Regarding the consequences of inheritance rules, Berkner and Mendels (1978) sum up mainstream anthropological research by stating that rules prescribing impartible inheritance (such as primogeniture or ultimogeniture) limit the number of marriages, encourage emigration of children, lead to slow population growth, and encourage the formation of the stem family where sons stay in the household of the parents after marriage. Partible inheritance, in contrast, is believed to lead to the fragmentation of land ownership, high marriage rates, rapid population growth, and the formation of nuclear families.

${ }^{5} \mathrm{~A}$ (French) acronym for nomenclature of territorial units for statistics used by Eurostat.

${ }^{6}$ It is essential to understand that the persistence in differences across countries is not meant to imply persistence in how the family is organized in each country over time. For a theoretical explanation of the persistence of family norms, see Cigno et al. $(2017,2020)$.
} 
In this study, we use family types as an explanatory variable for four groups of outcome variables, namely: (1) ideological convictions, (2) state formation, (3) constitutional structure, and (4) postconstitutional outcomes. The selection of these dependent variables is derived from Todd (1985) and we consider our analysis the first comprehensive empirical test of Todd's main arguments. Relying on a parsimonious model which includes a set of covariates that are exogenous to family types and potentially relevant to development, we find mixed evidence. Some of the results seem to support Todd's hypotheses concerning ideological convictions in the population, state formation, and post-constitutional outcomes; but there are no apparent effects on a country's constitutional structure. Countries where endogamous marriage is accepted or even expected suffer from weaker states, a finding that is in line with theoretical considerations about state formation. We also find that the onset of industrialization began earlier and governments have shorter tenures in countries where the nuclear family type dominates, both considerations addressing post-constitutional outcomes.

The rest of the paper is structured as follows: in section 2, we define and categorize family systems and then move on to describe the various hypotheses linking family systems to different outcome variables. Our dataset is described in section 3 and section 4 contains the empirical results. Section 5 concludes with some suggestions for future research.

\section{Theory}

\subsection{The basic argument}

Todd's (1985) main conjecture is that family structures are stable and constitute blueprints for political systems. The relationship between state authority and the individual in a country accordingly reflects the relationship between father and son.

Throughout his book, Todd (1985) argues that family types are very stable over time, even more so than religious beliefs. Accordingly, family types impact religious beliefs and practices, rather than the other way around. Todd, for example, argues that religion as practiced in Europe took hold predominantly in authoritarian family systems (p. 117), and that Islam was only able to spread where family structures were open to endogamy (p. 134). ${ }^{7}$ For European countries, Todd (1990) spells out his general argument in more detail. Todd (2019) discusses various aspects of human development and provides a ballpark estimate for their stability over time. Accordingly, changes in economic development take 50 years, educational progress takes 500 years, and the evolution of family structures takes around 5,000 years. This schematic is reminiscent of Williamson's (2000) depiction of the levels of social analysis. Accordingly, family structures can be considered exogenous for most purposes.

Todd builds on his main conjecture that more aggregate societal characteristics and structures mirror family structures to generate a host of hypotheses. We assign each hypothesis to one of the four groups, which we discuss over the following sections.

\subsection{Effects on ideology}

Todd's (1985) book is titled 'The Explanation of Ideology'. The book's main thrust is to explain why some societies lean toward liberalism, while others prefer communism. ${ }^{8}$ The general argument used to explain ideological variation is that the ideological system of a society is a reflection of its family structure (p. 17).

\footnotetext{
${ }^{7}$ It is difficult to establish if family types are more stable over time than religion and other forms of culture. Schulz et al. (2019), for example, claim that the Catholic church systematically undermined cousin marriage in Medieval Europe and that this promoted individualism and other cultural traits (see also Goody, 2000 and more recently Henrich, 2020). Chaney (2020) argues that cousin marriage explains the spread of traditionalist interpretations of Islam, rather than the other way around. Regarding inheritance norms, Ekelund et al. (2002) find that during the Protestant Reformation societies relying on primogeniture by and large remained Catholic, whereas those with partible inheritance were more likely to become Protestant. It is beyond the scope of this analysis to disentangle the causal relationships between family types and other forms of culture. The durability of family types, however, is essential to Todd's theory and empirical evidence to support it is discussed in the Introduction.

${ }^{8}$ Todd (1985: 5) names seven ideologies whose prevalence he wants to explain by drawing on family structures, namely communism, liberalism, Catholicism, social democracy, Hinduism, Islam, and Buddhism.
} 
The nuclear family types, no matter whether absolute or egalitarian, are conducive to individualism. Because children living in nuclear families are not expected to stay in their parents' household after marrying and possibly becoming parents, they experience more liberty than children living in the other types of families. Todd (1985: 120) argues that the resulting individualism implies more tolerance toward others and less xenophobia. ${ }^{9}$ In authoritarian systems, however, brothers are not considered equal and racism may reflect that inequality at the societal level. Todd (1985: 61) explains that the authoritarian family's focus on household continuity also leads to racism, because the family may want to preserve the status quo in a biological sense. Formulated as Hypothesis 1: Societies dominated by nuclear family types display lower levels of racism than other societies. Berggren et al. (2019) study dozens of potential determinants of tolerance, but family types are not among them.

Todd (1985: 148) also argues that, compared to the other family types, the endogamous community family type grants individuals the least freedom of choice regarding marriage partners by subjecting this choice to much stricter customary rules. The nuclear family leaves the choice of the marriage partner to the individual. Both the authoritarian and exogamous community family types give the parents the right to organize the lives of their children, including the choice of marriage partner. Formulated as Hypothesis 2: Members of societies dominated by the endogamous family type perceive themselves as having less control over their own lives than those in other societies. ${ }^{10}$

\subsection{Effects on state formation}

In developing his arguments regarding family structures as potential determinants of state formation, Todd (1985) refers to Max Weber (1919). Weber envisioned the ideal state as the realization of superior rationality embodied in a bureaucracy that is founded on merit only. Weber believed that the state would eventually take hold everywhere.

Todd (1985: 144) points out that the Weberian view of the state relies on depersonalized relationships between the administration and the citizens. Since some family types are more compatible with such a depersonalized structure than others, one would expect societies to be differently compatible with Weber's vision of state formation. Todd predicts that exogamy leads to the development of the state, whereas endogamy leads to societies that do not rely on a state, but rather on clans and clan loyalty. ${ }^{11}$ Formulated as Hypothesis 3: Societies dominated by the endogamous family type are less likely to form strong state structures than other societies. This has implications for the age of statehood (i.e. how early a state was formed), but also for the capacity and reach of the modern state.

\subsection{Effects on constitutional structure}

The main trait of the rule of law is to make everyone subject to the same laws, no matter whether they are rich or poor, young or old, politically connected or not. When brothers are not treated as equals and if family structures are mirrored in the constitutional structure of a country, then we should not expect that societies with an authoritarian family structure reach high rule of law levels. In these societies, 'all men are not considered equal' (1985: 55). Accordingly, Hypothesis 4 is: Societies dominated by the authoritarian family type exhibit lower rule of law levels than other societies. Licht et al. (2007), Berggren and Bjørnskov (2013), and Gutmann and Voigt (2018) have argued that culture is an important determinant of the rule of law, but none of them have considered family types in their analysis.

According to Todd, a third important dimension of constitutional design is also impacted by family structures, namely the choice between a unitary and a federal state structure. The scant literature on

\footnotetext{
${ }^{9}$ There is also a sizable literature on the effects of individualism (including Davis, 2016; Davis and Williamson, 2019 or Gorodnichenko and Roland, 2017, 2020), which Todd would consider a mediating factor between family types and some of their ideological consequences.

${ }^{10}$ Although (historical) liberty in the family has not been related to control perceptions, Nikolaev and Bennett (2016) and Pitlik and Rode (2016) demonstrate a robust effect of economic freedom on control perceptions.

${ }^{11}$ Gutmann and Voigt (2020) hypothesize that the historical practice of endogamy is linked to a higher relevance of traditional law under modern nation states, but they find no empirical evidence for this conjecture.
} 
the determinants of federalism ignores family structures. Todd suggests that authoritarian family structures are incompatible with the formation of a unitary state. Hypothesis 5: Societies dominated by the authoritarian family type are more likely to be federally organized than other societies.

\subsection{Effects on post-constitutional outcomes}

Todd observes that nuclear family structures can produce two political models, one liberal, 'the other oscillating between extremes of anarchism and militarism' (Todd, 1985: 103f.). Todd predicts that the two models share one trait: governmental instability. Under the liberal model, frequent government turnover results from elections; in the oscillating model, it follows from military coups. In countries with authoritarian family structures, the voters rarely change their mind, often making the same choice as in the previous election (ibid.: 68). The underlying argument is that in these countries, the hierarchical parent-child relationship makes the young learn how to behave 'correctly', after which they rarely question or change their behavior. Todd's immediate hypothesis that the proportion of swing voters is lower in these countries than in countries in which the nuclear family dominates is difficult to test, due to lack of data. But, there is a direct implication that can be tested. Rephrased as Hypothesis 6: Societies dominated by nuclear family types experience more frequent government turnover than societies dominated by the authoritarian family type.

One of the first measures taken in office by would-be autocrats in order to expand their power is to weaken civil society. Todd (1985: 103) observes that countries in which nuclear family systems dominate are more immune to totalitarian ideologies and to political systems that try to eliminate civil society. Phrased as Hypothesis 7: Societies dominated by nuclear family types have a more vivid civil society than other societies. Reher (1998) formulates a complementary argument: civic association serves as a substitute for strong family ties.

We conclude this tour d'horizon of the political and social consequences of family types with the possible consequences for economic development. ${ }^{12}$ The nuclear family structure increases people's mobility, as they do not stay in their parents' household after getting married. Increased mobility can have important consequences, such as faster urbanization and industrialization, a better matching of labor with physical capital, etc. Hypothesis 8 focuses on the issue of industrialization: Societies dominated by nuclear family types are industrialized earlier than other societies. Greif (2006) argues, analogously to what Reher (1998) conjectures for civil society organizations, that corporations are more likely to emerge in an environment of nuclear families, favoring capital accumulation and factor mobility, both of which would lay the foundation for early industrialization.

Closely related to this is the conjecture that family structures in which households are shared by three or more generations are detrimental to innovation. If married children remain under the tutelage of their parents, parents are likely to influence many important decisions in the household. Given that older people have a lower propensity to innovate and people would learn only late in their life to make decisions independently, innovativeness in such societies should be lower. Formulated as Hypothesis 9: Societies dominated by nuclear family types are more innovative than other societies. Again, Greif (2006) would claim that at least some of this effect is due to stronger reliance on corporations.

Finally, Todd (1985) claims that in countries where the authoritarian family structure dominates people learn to accept inequality in interpersonal relations. Yet, Todd observes that 'ironically, the economic structure of countries with an authoritarian family system is almost always relatively egalitarian' (ibid.: 61). The mechanism through which this unexpected result is achieved is the conservation of peasant holdings via primogeniture. This avoids that many property owners have parcels so small that they cannot live from the proceeds and are forced to sell their land to capitalists. In other

\footnotetext{
${ }^{12} \mathrm{We}$ are not studying income per capita as an outcome, as Todd does not formulate a corresponding prediction. However, Le Bris (2020) takes up this question. He uses data from Todd to create a 'family score'. Le Bris interprets his findings as robust evidence for a causal effect of family characteristics on economic development.
} 
Table 2. Hypotheses and dependent variables

\begin{tabular}{lll}
\hline Hypothesis & Dependent variable & Group \\
\cline { 1 - 2 } & Racism & Ideology \\
\hline 2 & Control over own life & State formation \\
\hline 3 & Strength of state & Constitutional structure \\
\hline 4 & Rule of law & \\
\hline 5 & Federal structure & \\
\hline 7 & Government turnover & \\
\hline 8 & Civil society & \\
\hline 10 & Timing of industrialization & \\
\hline
\end{tabular}

words: primogeniture prevents a concentration of landed property. Formulated as Hypothesis 10: Societies dominated by the authoritarian family type are characterized by lower levels of income inequality than societies dominated by communitarian or nuclear family types. ${ }^{13}$

This concludes our overview of the hypotheses to be tested. Table 2 lists the dependent variables corresponding to each of our 10 hypotheses.

\section{Data and estimation approach}

Our estimation approach is in line with that employed in previous studies on the deep causes of development (see, e.g. Gutmann and Voigt, 2018 or Spolaore and Wacziarg, 2013). We estimate crosscountry regressions using ordinary least squares (OLS) and regression tables report robust standard errors. Based on these robust standard errors, each regression table also reports $p$-values of the $t$-tests needed to evaluate our hypotheses.

Empirically testing the hypotheses derived from Todd (1985) requires data on the family structures that were historically prevalent in a society. Recently, a dataset on family characteristics has been introduced by Rijpma and Carmichael (2016). In addition to the original coding by Todd, they rely on Murdock's (1981) Ethnographic Atlas, which was first published in 1967 and contains detailed information on 1,267 societies. To aggregate information from these societies at the nation state level, Rijpma and Carmichael follow a procedure implemented by Bolt (2012). Matching the data from Todd and Murdock, Rijpma and Carmichael find that 49 out of 102 countries are measured consistently across the two data sources. This is less than half of all possible cases. Rijpma and Carmichael then try to identify the relative strengths and weaknesses of the information provided by the two datasets and utilize this to create a consolidated (or as they call it, hybrid) dataset covering 162 countries. To better understand the characteristics of the data we are relying on, we compare it to other measures of the dominant family structures in nation states. Schulz (2020) provides information on the practice of cousin marriage, which we can easily compare to the hybrid family types by Rijpma and Carmichael (2016). To compare our data on family types with that of Alesina et al. (2015), we rely on their main indicator for family ties: based on the World Values Survey and the European Values Study, we measure the share of the population above the age of 18 who are still living with their parents. Family types, which describe the historical organization of the family, are fundamentally different from family ties, which simply measure the likelihood of contemporary adults to live with their parents.

\footnotetext{
${ }^{13}$ This would be consistent with the evidence provided by Duranton et al. (2009) for regional differences within Europe due to family types.
} 
To test the many hypotheses introduced above, we rely on dependent variables from multiple data sources. We use survey responses from the World Values Survey and the European Values Study to measure the population share that would not like to have neighbors of a different race, as well as the average perception in the population of being in control of one's own life. From the Polity IV project, we use the State Fragility Index and its two sub-indicators that measure a state's legitimacy and effectiveness. Indicators for the rule of law and government effectiveness come from the World Bank's Worldwide Governance Indicators. ${ }^{14}$ Data on a country's federal organization are taken from Norris (2015). From the V-DEM dataset, we use the Core Civil Society Index, which is a measure of the robustness of civil society. We use information from the Archigos dataset to construct an indicator for the frequency of political leadership turnover, i.e. the mean length of leadership spells in a country. Data on income inequality before and after government transfers are from Solt's (2016) Standardized World Income Inequality Database. To measure the historical adoption of new technologies, we rely on data from Comin et al. (2010). Data on the historical timing of industrialization, defined as the year in which employment in industry exceeded that in agriculture, come from Bentzen et al. (2013).

Table 3 shows the descriptive statistics for our dependent variables and the indicators for family types, giving us a first impression of some patterns in the data. Surprisingly, the authoritarian family type is associated with the weakest family ties, even though this family type is characterized by adult sons historically living with their parents. It is reassuring that at least the endogamous community family type, which shares this characteristic, exhibits the strongest family ties of all family types. This may suggest that endogamy is conducive to sons living under one roof with their parents. Regarding the practice of cousin marriage, as measured by Schulz (2020), it is not surprising that the endogamous community family type exhibits significantly more cousin marriages than any other family type, but it is followed by the exogamous community type (and the African/Anomic family types), which suggests that a comparison between community family types is not a good way to identify the consequences of endogamy.

As control variables, we use the set of standard indicators employed by Spolaore and Wacziarg (2013) to explain long run development: latitude, population-adjusted state antiquity, the share of tropical land area, and dummy variables that indicate whether the country is landlocked and whether it is an island. Moreover, we add control variables for the ruggedness of a country's landscape, its distance to the next coastline (both from Nunn and Puga, 2012), its malaria ecology (Kiszewski et al., 2004), the fraction of the population residing in the regions of high malaria risk (Gallup and Sachs, 2001), and historical hunter-gatherer subsistence (Enke, 2019), as well as an indicator of linguistic fractionalization (Desmet et al., 2012).

Some of the hypotheses introduced by Todd aim at the comparison between two specific family types, such as 'the nuclear family type does better than the authoritarian type'. Our analysis follows a systematic approach in that we control for the same set of family types and control variables for all dependent variables. The fact that the estimated models differ only in terms of their dependent variable and the corresponding sample size ensures an easy interpretation of the results as well as their comparability across models. Countries coded as having an 'African' family type or an 'anomic' family type form the omitted category. ${ }^{15}$ The absolute and egalitarian nuclear family types are combined in one binary variable (simply labeled nuclear). The authoritarian family type is represented by another dummy variable. The large number of countries dominated by a communitarian family type is split up according to the permissibility of endogamy, resulting in endogamous and exogamous communitarian family types. However, it should be noted that cousin marriage is practiced somewhat frequently in both family types according to the data by Schulz (2020).

\footnotetext{
${ }^{14}$ Gutmann and Voigt (2018) show that this indicator is largely consistent with one that is constructed based on a clear theoretical concept of the rule of law, suggesting that it is a reasonable indicator to work with if country or time coverage is a concern.

${ }^{15}$ Todd (1985: 25f.) describes the African family type as being based on unstable household forms. The anomic family type is characterized by a substantial discrepancy between rules and practiced family organization (ibid.: 171).
} 
Table 3. Descriptive statistics

\begin{tabular}{|c|c|c|c|c|c|c|c|c|c|}
\hline & Mean & SD & Min & Max & Nuclear & Authorit. & Endo.Com. & Exo.Com. & Afr./Anom. \\
\hline Nuclear & 0.24 & 0.43 & 0 & 1 & 1 & 0 & 0 & 0 & 0 \\
\hline Authoritarian & 0.10 & 0.30 & 0 & 1 & 0 & 1 & 0 & 0 & 0 \\
\hline Endogamous community & 0.21 & 0.41 & 0 & 1 & 0 & 0 & 1 & 0 & 0 \\
\hline Exogamous community & 0.21 & 0.41 & 0 & 1 & 0 & 0 & 0 & 1 & 0 \\
\hline WVS: racism & 0.21 & 0.13 & 0.02 & 0.58 & $0.14^{\star}$ & 0.15 & $0.32^{\star}$ & 0.24 & 0.21 \\
\hline WVS: control & 0.65 & 0.08 & 0.45 & 0.79 & 0.67 & 0.67 & 0.63 & $0.61^{\star}$ & 0.68 \\
\hline State Antiquity Index & 0.54 & 0.21 & 0.08 & 0.96 & $0.64^{*}$ & $0.70^{*}$ & 0.55 & 0.56 & $0.38^{*}$ \\
\hline State Fragility Index (SFI) & 9.37 & 6.40 & 0.00 & 23.33 & $6.22^{*}$ & $2.18^{*}$ & $12.30^{\star}$ & 8.83 & $12.63^{*}$ \\
\hline SFI-effectiveness & 4.69 & 3.55 & 0.00 & 12.17 & $3.05^{\star}$ & $0.97^{\star}$ & $5.91^{*}$ & 4.47 & $6.60^{*}$ \\
\hline SFI-legitimacy & 4.68 & 3.16 & 0.00 & 11.46 & $3.17^{\star}$ & $1.21^{\star}$ & $6.39^{\star}$ & 4.35 & $6.03^{*}$ \\
\hline WGI: government effectiveness & -0.03 & 1.00 & -2.15 & 2.16 & $0.41^{\star}$ & $1.27^{\star}$ & $-0.46^{\star}$ & -0.12 & $-0.51^{*}$ \\
\hline WGI: Rule of Law & -0.07 & 1.03 & -2.31 & 1.98 & $0.39^{*}$ & $1.26^{*}$ & $-0.48^{\star}$ & -0.20 & $-0.54^{\star}$ \\
\hline Federalism & 0.28 & 0.45 & 0 & 1 & 0.42 & 0.44 & $0.13^{*}$ & 0.23 & 0.27 \\
\hline Avg. Time in office for leader & 9.31 & 6.46 & 1.01 & 49.00 & $6.43^{\star}$ & $5.38^{*}$ & $12.45^{\star}$ & 10.76 & 9.28 \\
\hline V-DEM: civil society & 0.43 & 0.21 & 0.07 & 0.90 & $0.51^{\star}$ & $0.58^{*}$ & $0.28^{\star}$ & 0.46 & 0.41 \\
\hline Year of industrialization & 1986 & 33.29 & 1801 & 2005 & $1972^{\star}$ & $1946^{\star}$ & $2000^{*}$ & 1990 & $2002^{\star}$ \\
\hline Technology 1000BC & 0.45 & 0.28 & 0.00 & 1.00 & 0.40 & 0.52 & $0.65^{\star}$ & 0.55 & $0.28^{*}$ \\
\hline Technology $1 \mathrm{AD}$ & 0.74 & 0.28 & 0.00 & 1.00 & $0.59^{\star}$ & $0.97^{\star}$ & $0.94^{*}$ & 0.78 & $0.59^{\star}$ \\
\hline Technology 1500AD & 0.49 & 0.32 & 0.00 & 1.00 & 0.46 & $0.87^{\star}$ & 0.57 & $0.66^{\star}$ & $0.24^{\star}$ \\
\hline Technology 2000AD & 0.46 & 0.2 & 0.17 & 1.01 & $0.56^{\star}$ & $0.81^{\star}$ & $0.35^{\star}$ & 0.44 & $0.35^{\star}$ \\
\hline Gini, before transfers & 0.45 & 0.07 & 0.24 & 0.69 & 0.46 & 0.43 & $0.42^{\star}$ & $0.43^{\star}$ & $0.49^{\star}$ \\
\hline Gini, after transfers & 0.39 & 0.08 & 0.23 & 0.66 & 0.37 & $0.30^{\star}$ & 0.39 & $0.35^{\star}$ & $0.47^{\star}$ \\
\hline Cousin marriage, share & 15.10 & 17.31 & 0.20 & 65.80 & $2.66^{\star}$ & $2.37^{\star}$ & $32.01^{*}$ & 16.27 & 9.44 \\
\hline WVS: family ties & 0.27 & 0.11 & 0.04 & 0.57 & 0.25 & $0.16^{\star}$ & $0.37^{\star}$ & 0.26 & 0.28 \\
\hline Observations (max.) & 164 & & & & 36 & 16 & 33 & 35 & 39 \\
\hline
\end{tabular}

Note: Right panel shows mean values under each family type.

* Difference to all other family types significant at the 5\% level. 
Table 4. Hypotheses 1 and 2

\begin{tabular}{|c|c|c|}
\hline & $(1)$ & $(2)$ \\
\hline & Racist & Control \\
\hline Absolute latitude & $-0.406^{\star \star}(0.142)$ & $-0.028(0.096)$ \\
\hline Tropical land area (\%) & $-0.107(0.089)$ & $0.007(0.051)$ \\
\hline Landlocked & $-0.046(0.026)$ & $-0.025(0.022)$ \\
\hline Island & $0.068(0.050)$ & $-0.017(0.031)$ \\
\hline Nuclear & $-0.039(0.053)$ & $-0.005(0.030)$ \\
\hline Authoritarian & $0.042(0.058)$ & $-0.005(0.036)$ \\
\hline Endogamous communitarian & $0.137^{\star \star}(0.048)$ & $-0.043(0.036)$ \\
\hline Exogamous communitarian & $0.118^{\star}(0.050)$ & $-0.060(0.033)$ \\
\hline Constant & $0.321^{\star \star \star}(0.070)$ & $0.689^{\star \star \star}(0.049)$ \\
\hline Nuclear $=0,[p]$ & {$[0.000]$} & \\
\hline EndoCom $=$ ExoCom, $[p]$ & & {$[0.611]$} \\
\hline EndoCom $=0,[p]$ & & {$[0.320]$} \\
\hline F-test (all family types) & $10.7^{\star \star \star}$ & $2.6^{\star}$ \\
\hline$N$ & 86 & 87 \\
\hline$R^{2}$ & 0.40 & 0.14 \\
\hline
\end{tabular}

Note: OLS coefficient estimates with robust standard errors in parentheses, $p$-values in brackets correspond to $t$-tests for our hypotheses, an $F$-test evaluates the joint statistical significance of all family type indicators.

${ }^{\star} 0.05,{ }^{\star \star} 0.01,{ }^{\star \star \star} 0.001$.

\section{Testing Todd}

\subsection{Family types and ideology}

Table 4 shows that there is significantly less racism in countries with a nuclear family structure than in other countries, which is in line with our first hypothesis. An unexpectedly strong association exists between racism and the communitarian family types. Both, the endogamous as well as the exogamous communitarian family type show significantly more racism than our reference category. Hypothesis 2 states that people living in countries dominated by the endogamous family type perceive themselves as having less control over their own lives. This is not confirmed by our results, which indicate that none of the family types exert an unusual influence on an individual's perception of how much control they have over their own life.

\subsection{Family types and state formation}

The results in Table 5 can be used to evaluate Todd's argument that endogamous family structures are an obstacle to state formation. Two aspects can be separated here: the time period for which the current state has existed without interruption (state antiquity) and the contemporaneous fragility of the state. For the uninterrupted existence of a state as such, we find no support for the argument that endogamy is a hindrance. Countries dominated by nuclear or authoritarian family types exhibit the earliest state formation, followed by communitarian family types, which in turn formed states earlier than countries of the African and anomic family type.

Moving from state antiquity to contemporaneous state fragility, we find that nuclear and authoritarian family types are the least fragile and that states dominated by the endogamous communitarian family type are more fragile than others. The difference between endogamous and exogamous 
Table 5. Hypothesis 3

\begin{tabular}{|c|c|c|c|c|c|}
\hline & (1) & $(2)$ & (3) & (4) & (5) \\
\hline & StateHist & Fragility (SFI) & SFI-effect & SFI-legit & WGI: GovEff \\
\hline Absolute latitude & $-0.190(0.175)$ & $-25.397^{\star \star \star}(3.872)$ & $-11.435^{\star \star \star}(2.282)$ & $-13.961^{\star \star \star}(1.847)$ & $2.628^{* \star *}(0.605)$ \\
\hline Tropical land area (\%) & $-0.141(0.079)$ & $-0.360(1.619)$ & $0.534(1.009)$ & $-0.894(0.741)$ & $-0.132(0.242)$ \\
\hline Landlocked & $-0.081^{\star}(0.036)$ & $3.753^{\star \star \star}(0.810)$ & $2.531^{\star \star \star}(0.475)$ & $1.222^{\star \star}(0.417)$ & $-0.487^{\star \star \star}(0.128)$ \\
\hline Island & $0.009(0.066)$ & $-0.118(1.248)$ & $0.390(0.965)$ & $-0.508(0.447)$ & $0.258(0.248)$ \\
\hline Nuclear & $0.219^{\star \star \star}(0.063)$ & $-1.634(1.108)$ & $-1.052(0.699)$ & $-0.582(0.527)$ & $0.363^{\star}(0.181)$ \\
\hline Authoritarian & $0.315^{\star \star *}(0.077)$ & $-1.852(1.408)$ & $-1.456(0.825)$ & $-0.396(0.706)$ & $0.978^{\star \star \star}(0.196)$ \\
\hline Endogamous communitarian & $0.128^{\star}(0.063)$ & $3.742^{\star \star}(1.175)$ & $1.649^{\star}(0.713)$ & $2.093^{\star * *}(0.596)$ & $-0.413^{*}(0.167)$ \\
\hline Exogamous communitarian & $0.134^{\star}(0.065)$ & $2.602(1.361)$ & $1.185(0.869)$ & $1.417^{\star}(0.648)$ & $-0.455^{\star}(0.191)$ \\
\hline Constant & $0.516^{\star \star \star}(0.070)$ & $14.577^{\star \star \star}(1.550)$ & $6.728^{\star \star \star}(0.943)$ & $7.849^{\star \star \star}(0.724)$ & $-0.611^{*}(0.237)$ \\
\hline EndoCom = ExoCom, $[p]$ & {$[0.916]$} & {$[0.374]$} & {$[0.544]$} & {$[0.299]$} & {$[0.821]$} \\
\hline EndoCom $=0,[p]$ & {$[0.960]$} & {$[0.000]$} & {$[0.002]$} & {$[0.000]$} & {$[0.001]$} \\
\hline F-test (all family types) & $5.4^{\star \star \star}$ & $10.4^{\star \star \star}$ & $8.4^{\star \star \star}$ & $9.4^{\star \star \star}$ & $22.9^{\star \star \star *}$ \\
\hline N & 119 & 133 & 133 & 133 & 136 \\
\hline$R^{2}$ & 0.32 & 0.63 & 0.56 & 0.61 & 0.61 \\
\hline
\end{tabular}


Table 6. Hypotheses 4 and 5

\begin{tabular}{lll}
\hline & $(1)$ & $(2)$ \\
& ROL & FED \\
\hline Absolute latitude & $2.764^{\star \star \star}(0.613)$ & $-0.504(0.404)$ \\
\hline Tropical land area (\%) & $-0.162(0.255)$ & $-0.270(0.148)$ \\
\hline Landlocked & $-0.391^{*}(0.149)$ & $-0.254^{\star \star}(0.076)$ \\
\hline Island & $0.332(0.220)$ & $-0.017(0.144)$ \\
\hline Nuclear & $0.377^{\star}(0.186)$ & $0.124(0.132)$ \\
\hline Authoritarian & $0.946^{\star \star \star}(0.197)$ & $0.238(0.207)$ \\
\hline Endogamous communitarian & $-0.386^{\star}(0.187)$ & $-0.179(0.117)$ \\
\hline Exogamous communitarian & $-0.504^{\star \star}(0.192)$ & $0.007(0.125)$ \\
\hline Constant & $-0.728^{\star \star}(0.250)$ & $0.541^{\star \star *}(0.154)$ \\
\hline Authoritarian $=0,[p]$ & {$[0.000]$} & {$[0.181]$} \\
\hline F-test (all family types) & $18.9^{\star \star \star}$ & 2.3 \\
\hline$N$ & 137 & 135 \\
\hline$R^{2}$ & 0.58 & 0.12 \\
\hline
\end{tabular}

Note: See Table 4.

community family types is not statistically significant, but it should be kept in mind that exogamous community types have the second highest levels of practiced endogamy, as illustrated in Table 3. Regarding contemporaneous government effectiveness, the communitarian family types are again the worst performing. Interestingly, governments of countries with authoritarian family structures have by far the most effective governments. A possible interpretation of this finding is that it is easier for a government to be effective if the acceptance of (state) authority is the norm. Overall, the empirical evidence is consistent with hypothesis 3 . Although societies practicing endogamy were not later in forming states, they have not managed to bring about strong states with a high degree of legitimacy or effectiveness.

\subsection{Family types and constitutional structure}

Table 6 shows our results for two aspects of constitutional structure. For the rule of law, we observe a similar pattern as before: nuclear and authoritarian family types outperform the reference category, and communitarian family types underperform compared to the reference category. Interestingly, authoritarian family types perform much better than all other family types, which contradicts Todd's prediction, as spelled out in hypothesis 4 . One could infer from this that the acceptance of authority is not only favorable for government effectiveness, but also for high levels of the rule of law.

Todd expected citizens of countries with an exogamous communitarian family structure, such as Russia, Hungary, or Bulgaria, to be prone to adopting a socialist ideology. ${ }^{16}$ Although, he did not explicitly claim any association between the exogamous communitarian type and constitutional choice, we find low rule of law levels in these countries. Federalism is not statistically associated with a particular family type, which leads us to reject hypothesis 5 .

\footnotetext{
${ }^{16}$ Trying to make sense of the combination between the endogamous community family type and preferences in favor of socialism in the Muslim world, Todd (1985: 146f.) remarks that Islam only recognizes two levels of integration, namely the family and the community of all believers - the ummah. Arab socialism would, therefore, be unique in attempting to erect socialism without a state. Hall (2014) takes on the contrary perspective and studies the position of socialism and other ideologies vis-à-vis the family.
} 
Table 7. Hypotheses 6-8

\begin{tabular}{|c|c|c|c|}
\hline & (1) & $(2)$ & (3) \\
\hline & Tenure & CivSoc & Industr \\
\hline Absolute latitude & $-11.917^{\star}(5.199)$ & $0.687^{\star \star \star}(0.154)$ & $-113.590^{\star \star \star}(28.110)$ \\
\hline Tropical land area (\%) & $-1.846(1.830)$ & $0.096(0.062)$ & $-3.339(7.271)$ \\
\hline Landlocked & $0.883(1.191)$ & $-0.056(0.036)$ & $9.966^{\star}(4.633)$ \\
\hline Island & $3.177(2.724)$ & $0.025(0.057)$ & $-4.940(13.717)$ \\
\hline Nuclear & $-1.738(1.186)$ & $0.009(0.052)$ & $-9.198(5.612)$ \\
\hline Authoritarian & $-1.526(1.875)$ & $0.005(0.076)$ & $-20.876(13.568)$ \\
\hline Endogamous communitarian & $4.205^{\star}(1.823)$ & $-0.183^{\star \star \star}(0.045)$ & $13.065^{\star \star}(4.218)$ \\
\hline Exogamous communitarian & $3.391(2.552)$ & $-0.083(0.052)$ & $16.570^{\star}(6.808)$ \\
\hline Constant & $11.302^{\star \star \star}(1.878)$ & $0.291^{\star \star \star}(0.056)$ & $2014.216^{\star \star \star}(8.472)$ \\
\hline Nuclear $=$ Authoritarian, $[p]$ & {$[0.876]$} & & \\
\hline Nuclear $=0,[p]$ & & {$[0.060]$} & {$[0.040]$} \\
\hline F-test (all family types) & $5.6^{\star \star \star}$ & $6.4^{\star \star \star}$ & $7.8^{\star * \star}$ \\
\hline$N$ & 135 & 133 & 117 \\
\hline$R^{2}$ & 0.21 & 0.37 & 0.52 \\
\hline
\end{tabular}

Note: See Table 4.

\subsection{Family types and post-constitutional outcomes}

Todd predicts that countries characterized by a nuclear family type exhibit earlier industrialization, more frequent government turnover, and a more vivid civil society. Table 7 shows that only hypothesis 8 , which concerns the timing of industrialization, finds support in the data. The countries characterized by the endogamous communitarian type are again noteworthy. Their governments stay in power the longest, they have the weakest civil society, and industrialization happened significantly later than in countries that are not of the community family type. Again, the community family type is linked to adverse outcomes in development.

The validity of Todd's claim that nuclear family types are conducive to innovation can be judged based on the results presented in Table 8. The columns show measures of technology adoption from 3,000 years ago to the present (ordered from left to right). Indeed, nuclear families outperform the reference category of African and anomic family types, but only in modern times. More importantly, countries dominated by the nuclear family type were significantly lagging behind the rest of the world in technology adoption 2,000 years ago. After having caught up, they now significantly outperform other countries. Despite these impressive developments in nuclear family type countries, the authoritarian family type shows even more innovativeness and consistently outperformed nuclear family types over the last 2,000 years. Communitarian family types show a particularly interesting time trend. They were highly innovative until the middle ages, but completely lost this advantage over the time period between 1500 and 2000AD. These findings are reminiscent of a 'reversal of fortunes' that has been addressed with regard to the Muslim world under headings such as 'what went wrong?' (Lewis, 2002; see also Kuran, 2011). Lewis (2002) recounts the well-known story that the Muslim world used to be leading in innovation and technology but refused to adopt technologies developed elsewhere, which caused its relative decline over the last five centuries. Kuran $(2005,2011)$ attributes responsibility for the relative economic decline of the Middle East to the absence of the concept of a corporation, which enjoys legal personhood. If societies are used for organizing transactions within extensive family networks, this might explain resistance to the idea of economic partnerships in 
Table 8. Hypothesis 9

\begin{tabular}{|c|c|c|c|c|}
\hline & (1) & $(2)$ & (3) & (4) \\
\hline & Inno1000BC & InnolAD & Inno1500AD & Inno2000AD \\
\hline Absolute latitude & $0.255(0.241)$ & $-0.010(0.232)$ & $0.903^{\star \star \star}(0.260)$ & $0.583^{\star \star \star}(0.109)$ \\
\hline Tropical land area (\%) & $-0.110(0.121)$ & $-0.148(0.101)$ & $0.043(0.108)$ & $-0.030(0.038)$ \\
\hline Landlocked & $-0.109(0.061)$ & $0.055(0.052)$ & $0.005(0.053)$ & $-0.125^{\star \star \star}(0.023)$ \\
\hline Island & $0.000(0.120)$ & $0.035(0.116)$ & $0.122(0.116)$ & $0.029(0.055)$ \\
\hline Nuclear & $0.034(0.068)$ & $-0.029(0.072)$ & $0.074(0.075)$ & $0.080^{*}(0.036)$ \\
\hline Authoritarian & $0.096(0.089)$ & $0.305^{\star \star \star}(0.077)$ & $0.293^{\star \star \star}(0.083)$ & $0.203^{\star \star \star}(0.046)$ \\
\hline Endogamous communitarian & $0.302^{\star \star}(0.096)$ & $0.292^{\star \star \star}(0.056)$ & $0.231^{\star \star \star}(0.060)$ & $-0.103^{\star \star \star}(0.025)$ \\
\hline Exogamous communitarian & $0.155^{\star}(0.076)$ & $0.136(0.072)$ & $0.199^{\star}(0.082)$ & $-0.092^{\star \star}(0.035)$ \\
\hline Constant & $0.335^{\star \star}(0.117)$ & $0.656^{\star \star \star}(0.086)$ & $0.099(0.097)$ & $0.336^{\star \star \star}(0.038)$ \\
\hline Nuclear $=0,[p]$ & [0.133] & {$[0.011]$} & [0.244] & {$[0.003]$} \\
\hline$F$-test (all family types) & $3.3^{\star}$ & $9.8^{\star \star \star}$ & $4.7^{\star \star}$ & $25.1^{\star \star \star}$ \\
\hline$N$ & 99 & 115 & 105 & 114 \\
\hline$R^{2}$ & 0.31 & 0.36 & 0.50 & 0.71 \\
\hline
\end{tabular}

Note: See Table 4.

Table 9. Hypothesis 10

\begin{tabular}{llc}
\hline & $(1)$ & $(2)$ \\
& GINI-PRE & GINI-POST \\
\hline Absolute latitude & $-0.025(0.049)$ & $-0.309^{\star \star \star}(0.048)$ \\
\hline Tropical land area (\%) & $-0.008(0.025)$ & $-0.028(0.026)$ \\
\hline Landlocked & $-0.008(0.014)$ & $-0.009(0.013)$ \\
\hline Island & $0.001(0.017)$ & $-0.008(0.019)$ \\
\hline Nuclear & $-0.028(0.021)$ & $-0.045^{\star}(0.021)$ \\
\hline Authoritarian & $-0.057^{\star}(0.025)$ & $-0.092^{\star \star \star}(0.022)$ \\
\hline Endogamous communitarian & $-0.079^{\star \star \star}(0.020)$ & $-0.047^{\star}(0.019)$ \\
\hline Exogamous communitarian & $-0.065^{\star \star}(0.022)$ & $-0.056^{\star \star}(0.020)$ \\
\hline Constant & $0.505^{\star \star \star}(0.027)$ & $0.524^{\star \star *}(0.027)$ \\
\hline Nuclear =Authoritarian, $[p]$ & {$[0.079]$} & {$[0.002]$} \\
\hline Authoritarian = Communitarian, $[p]$ & {$[0.426]$} & {$[0.001]$} \\
\hline$F$-test (all family types) & $5.7^{\star \star *}$ & $5.0^{\star \star *}$ \\
\hline$N$ & 134 & 134 \\
\hline$R^{2}$ & 0.22 & 0.60 \\
\hline
\end{tabular}

Note: See Table 4.

which a transaction partner is substitutable via the tradability of shares. The resulting small scale and brief lifespan of companies would have proved detrimental to the way European innovation evolved during the industrial revolution. Consistent with our previous findings, communitarian family 
types show the lowest levels of contemporaneous innovativeness and technology adoption. In sum, hypothesis 9 is supported by our findings in the sense that societies in which the nuclear family type dominates are more innovative than other societies. However, societies in which the authoritarian family type dominates are even more innovative.

Table 9 assesses the veracity of Todd's claim that the authoritarian family type is linked to less income inequality than the nuclear family type or the community family types. This prediction by Todd is indeed borne out by the data, but only after income is redistributed by the state. Countries of the authoritarian family type show the lowest levels of post-redistribution income inequality. This means that countries dominated by the authoritarian family type use the state to reduce income inequality more than any other family type. In conclusion, hypothesis 10 is also supported by the data.

To evaluate the robustness of our findings, we have added a number of additional control variables to each regression model. The timing of the transition from hunter-gatherer to agricultural or pastoral subsistence as well as pathogen stress due to malaria have been suggested by Enke (2019) as causes of variation in kinship tightness. Terrain ruggedness and distance to the coastline have been proposed by Giuliano and Nunn (2018) as control variables. Finally, we control for a measure of linguistic diversity, which Desmet et al. (2012) have shown has important political and economic consequences. The data sources are described in section 3 . None of our empirical results are substantively changed by including the additional control variables one at a time. Regression results are available on request.

\section{Conclusion and outlook}

In economics, the search for the deep determinants of economic development has seen a renaissance over the last two decades (Spolaore and Wacziarg, 2013). Geographical factors play a central role in this quest. Simultaneously, a discussion regarding the relevance of culture for development emerged (e.g. Davis, 2016; Gorodnichenko and Roland, 2017, 2020). This study adds to our understanding of the deep roots of development by analyzing the association between family types and four groups of outcome variables: (1) ideological preferences, (2) state formation, (3) constitutional choice, and (4) post-constitutional outcomes. The hypotheses we test here are all derived from Todd (1985) whose work has been influential in the social sciences. Many of Todd's sweeping claims cannot be corroborated by our systematic empirical analysis.

Most of the hypotheses regarding the authoritarian family type were refuted. In theory, this family type embodies values that promote little personal freedom and accept inequality. These values are the polar opposite of those promoted by the French revolution: individual freedom and equality for all. However, our results show that people in countries dominated by the authoritarian family type are more innovative and have managed to implement both higher levels of the rule of law and more effective governments than countries dominated by the nuclear family types. Countries in which the authoritarian family type dominates also achieve the lowest level of post-redistribution income inequality.

Another noteworthy observation is that the two communitarian subcategories (endogamous and exogamous) have a number of problems in common: both are associated with more racism, low levels of the rule of law, and late industrialization. The advantage these countries originally enjoyed in innovation has turned into a disadvantage in the present. There are two outcome variables for which the endogamous community family type performs significantly worse than the exogamous community type: state fragility and civil society.

We had to make a number of assumptions in our analysis. Future research might attempt to address some of them. Coding countries as having a single, dominant family structure, for example, is convenient, but not necessarily accurate. In a more recent book, Todd (1990) himself codes European regions individually and identifies six different family types in different parts of France alone. Heterogeneity in family structures within a country constitutes an opportunity, because it allows us to test whether different family structures lead to significantly different economic or cultural outcomes, while formal institutions are - at least de jure - uniform across the country. It could, 
hence, be interesting to extend the analysis of Duranton et al. (2009) and ask if regions with different family structures are inhabited by people with different attitudes (see, e.g. Gutmann and Voigt, 2021). One could even think of a regression discontinuity design, if 'sharp' borders between different family types can be identified. A sharp border that is mentioned time and again in the literature is that between Göttingen and Calenberg (both located in lower Saxony, Germany; see Berkner, 1976). Others have criticized the coding of the family types tout court (e.g. Szołtysek and Poniat, 2018). Taking that criticism seriously, one might want to inquire into the effects of family structures relying on alternative data sources.

\section{References}

Acemoglu, D., S. Johnson and J. A. Robinson (2001), 'The Colonial Origins of Comparative Development: An Empirical Investigation', The American Economic Review, 91(5): 1369-1401.

Alesina, A. and P. Giuliano (2011), 'Family Ties and Political Participation', Journal of the European Economic Association, 9 (5): 817-839.

Alesina, A. and P. Giuliano (2014), 'Family ties', in P. Aghion and S. Durlauf (eds), Handbook of Economic Growth (Vol. 2), North-Holland: Elsevier, pp. 177-215.

Alesina, A., Y. Algan, P. Cahuc and P. Giuliano (2015), 'Family Values and the Regulation of Labor', Journal of the European Economic Association, 13(4): 599-630.

Ashraf, Q. and O. Galor (2013), 'The "Out of Africa” Hypothesis, Human Genetic Diversity, and Comparative Economic Development', The American Economic Review, 103(1): 1-46.

Becker, G. S. (1981), A Treatise on the Family, Cambridge: Harvard University Press.

Bentzen, J. S., N. Kaarsen and A. M. Wingender (2013), The Timing of Industrialization Across Countries, University of Copenhagen, Department of Economics, Discussion Paper No. 13-17.

Berggren, N. and C. Bjørnskov (2013), 'Does Religiosity Promote Property Rights and the Rule of Law?', Journal of Institutional Economics, 9(2): 161-185.

Berggren, N., M. Ljunge and T. Nilsson (2019), 'Roots of Tolerance among Second-Generation Immigrants', Journal of Institutional Economics, 15(6): 999-1016.

Berkner, L. K. (1976), 'Inheritance, Land Tenure and Peasant Family Structure: A German Regional Comparison', in J. R. Goody, J. Thirsk and E. P. Thompson (eds.), Family and Inheritance: Rural Society in Western Europe, 1200-1800, Cambridge: Cambridge University Press, pp. 71-95.

Berkner, L. and F. Mendels (1978), 'Inheritance Systems, Family Structure and Demographical Patterns in Western Europe, 1700-1900', in Charles Tilly (ed.), Historical Studies of Changing Fertility, Princeton: Princeton University Press, pp. 209-223.

Bertrand, M. and A. Schoar (2006), 'The Role of Family in Family Firms', Journal of Economic Perspectives, 20(2): 73-96.

Bolt, J. (2012), A new Database on the Origins of Institutional Development, University of Groningen, Working Paper.

Bonoldi, A., C. Dalle Nogare and N. Potrafke (2020), 'Do Inheritance Rules Affect Voter Turnout? Evidence from an Alpine Region', Constitutional Political Economy, 31(4): 395-445.

Broms, R. and A. Kokkonen (2019), 'Inheritance Regimes: Medieval Family Structures and Current Institutional Quality', Governance, 32(4): 619-637.

Chaney, E. J. (2020), 'Islam and Political Structure in Historical Perspective', in M. Cammett and P. Jones (eds.), The Oxford Handbook of Politics in Muslim Societies. doi: 10.1093/oxfordhb/9780190931056.013.6

Cigno, A., A. Gioffré and A. Luporini (2020), 'Evolution of Individual Preferences and Persistence of Family Rules', Review of Economics of the Household, forthcoming.

Cigno, A., M. Komura and A. Luporini (2017), 'Self-enforcing Family Rules, Marriage and the (Non)Neutrality of Public Intervention', Journal of Population Economics, 30(3): 805-834.

Comin, D., W. R. Easterly and W. Gong (2010), 'Was the Wealth of Nations Determined in 1000 BC?', American Economic Journal: Macroeconomics, 2(3): 65-97.

Davis, L. S. (2016), 'Individual Responsibility and Economic Development: Evidence from Rainfall Data', Kyklos, 69(3): 426-470.

Davis, L. S. and F. Abdurazokzoda (2016), 'Language, Culture and Institutions: Evidence from a New Linguistic Dataset', Journal of Comparative Economics, 44(3): 541-561.

Davis, L. S. and C. R. Williamson (2019), 'Does Individualism Promote Gender Equality?', World Development, $123: 104627$.

Davis, L. S. and C. R. Williamson (2020), 'Cultural Roots of Family Ties', Journal of Institutional Economics, 16(6): 785-808.

De La Croix, D. and F. Perrin (2018), 'How Far can Economic Incentives Explain the French Fertility and Education Transition?', European Economic Review, 108: 221-245.

Desmet, K., I. Ortuño-Ortína and R. Wacziarg (2012), 'The Political Economy of Linguistic Cleavages', Journal of Development Economics, 97(2): 322-338. 
Dilli, S. (2016), 'Family Systems and the Historical Roots of Global Gaps in Democracy', Economic History of Developing Regions, 31(1): 82-135.

Duranton, G., A. Rodríguez-Pose and R. Sandall (2009), 'Family Types and the Persistence of Regional Disparities in Europe', Economic Geography, 85(1): 23-47.

Ekelund, R. B., R. F. Hébert and R. D. Tollison (2002), 'An Economic Analysis of the Protestant Reformation', Journal of Political Economy, 110(3): 646-671.

Ellul, A., M. Pagano and F. Panunzi (2010), 'Inheritance Law and Investment in Family Firms', The American Economic Review, 100(5): 2414-2450.

Enke, B. (2019), 'Kinship, Cooperation, and the Evolution of Moral Systems', The Quarterly Journal of Economics, 134(2): 953-1019.

Galasso, V. and P. Profeta (2018), 'When the State Mirrors the Family: The Design of Pension Systems', Journal of the European Economic Association, 16(6): 1712-1763.

Gallup, J. L. and J. D. Sachs (2001), 'The Economic Burden of Malaria', The American Journal of Tropical Medicine and Hygiene, 64(1): 85-96.

Giuliano, P. and N. Nunn (2018), 'Ancestral Characteristics of Modern Populations', Economic History of Developing Regions, 33(1): 1-17.

Goody, J. (2000), The European Family, Oxford: Wiley-Blackwell.

Gorodnichenko, Y. and G. Roland (2017), 'Culture, Institutions, and the Wealth of Nations', Review of Economics and Statistics, 99(3): 402-416.

Gorodnichenko, Y. and G. Roland (2020), 'Culture, Institutions and Democratization', Public Choice, forthcoming.

Greif, A. (2006), 'Family Structure, Institutions, and Growth: The Origins and Implications of Western Corporations', The American Economic Review, 96(2): 308-312.

Gutmann, J. and S. Voigt (2018), 'The Rule of Law: Measurement and Deep Roots', European Journal of Political Economy, 54: 68-82.

Gutmann, J. and S. Voigt (2020), 'Traditional Law in Times of the Nation State: Why is it so Prevalent?', Journal of Institutional Economics, 16(4): 445-461.

Gutmann, J. and S. Voigt (2021), Family Types and the Spirit of Capitalism: Evidence From Regional Surveys, Paper presented at the Colloquium on the Foundations of the Market Order, University of Leipzig.

Hall, L. K. (2014), Family and the Politics of Moderation: Private Life, Public Goods, and the Rebirth of Social Individualism, Waco: Baylor University Press.

Henrich, J. (2020), The Weirdest People in the World: How the West Became Psychologically Peculiar and Particularly Prosperous, New York: Farrar, Straus and Giroux.

Kiszewski, A., A. Mellinger, A. Spielman, P. Malaney, S. E. Sachs and J. D. Sachs (2004), 'A Global Index Representing the Stability of Malaria Transmission', The American Journal of Tropical Medicine and Hygiene, 70(5): 486-498.

Kuran, T. (2005), 'The Absence of the Corporation in Islamic Law: Origins and Persistence', The American Journal of Comparative Law, 53(4): 785-834.

Kuran, T. (2011), The Long Divergence: How Islamic Law Held Back the Middle East, Princeton: Princeton University Press. Le Bris, D. (2020), Family Characteristics and Economic Development, Available at: https://dx.doi.org/10.2139/ssrn.2511173.

Le Play, F. (1895), L'organisation de la Famille Selon le Vrai Modèle Signalé par L'histoire de Toutes les Races et de Tous les Temps, Paris: Mame Publishers.

Lewis, B. (2002), What Went Wrong? The Clash Between Islam and Modernity in the Middle East, New York: Oxford University Press.

Licht, A., C. Goldschmidt and S. H. Schwartz (2007), 'Culture Rules: The Foundations of the Rule of Law and Other Norms of Governance', Journal of Comparative Economics, 35(4): 659-688.

Murdock, G. P. (1981), Atlas of World Cultures, Pittsburgh: University of Pittsburgh Press.

Nikolaev, B. and D. L. Bennett (2016), 'Give Me Liberty and Give Me Control: Economic Freedom, Control Perceptions and the Paradox of Choice', European Journal of Political Economy, 45: 39-52.

Norris, P. (2015), Democracy cross-national data, V4.0, at: www.pippanorris.com/data.

Nunn, N. and D. Puga (2012), 'Ruggedness: The Blessing of Bad Geography in Africa', Review of Economics and Statistics, 94 (1): 20-36.

Pitlik, H. and M. Rode (2016), 'Free to Choose? Economic Freedom, Relative Income, and Life Control Perceptions', International Journal of Wellbeing, 16(1): 81-100.

Reher, D. S. (1998), 'Family Ties in Western Europe: Persistent Contrasts', Population and Development Review, 24(2): $203-234$. Rijpma, A. and S. G. Carmichael (2016), 'Testing Todd and Matching Murdock: Global Data on Historical Family Characteristics', Economic History of Developing Regions, 31(1): 10-46.

Rodrik, D., A. Subramanian and F. Trebbi (2004), 'Institutions Rule: The Primacy of Institutions Over Geography and Integration in Economic Development', Journal of Economic Growth, 9(2): 131-165.

Sachs, J. D. (2003), Institutions don't rule: Direct effects of geography on per capita income, NBER Working Paper 9490.

Schulz, J. F. (2020), Kin Networks and Institutional Development, Avilable at: http://dx.doi.org/10.2139/ssrn.2877828. 
Schulz, J. F., D. Bahrami-Rad, J. P. Beauchamp and J. Henrich (2019), 'The Church, Intensive Kinship, and Global Psychological Variation', Science, 366(6466).

Solt, F. (2016), 'The Standardized World Income Inequality Database', Social Science Quarterly, 97(5): 1267-1281.

Spolaore, E. and R. Wacziarg (2009), 'The Diffusion of Development', The Quarterly Journal of Economics, 124(2): 469-529.

Spolaore, E. and R. Wacziarg (2013), 'How Deep are the Roots of Economic Development?', Journal of Economic Literature, 51(2): 325-369.

Szołtysek, M. and R. Poniat (2018), 'The Power of the Family: New Data Reveal the Role of the Historical Family as the Instigator of Disparate and Lasting Developmental Trajectories', World Values Research, 10(1): 1-39.

Todd, E. (1985), Explanation of Ideology: Family Structures and Social Systems, Oxford: Blackwell.

Todd, E. (1990), L'invention de L'Europe, Paris: Seuil.

Todd, E. (2019), Lineages of Modernity: A History of Humanity From the Stone age to Homo Americanus, Hoboken: John Wiley \& Sons.

Voigt, S. (2013), 'How (Not) to Measure Institutions', Journal of Institutional Economics, 9(1): 1-26.

Weber, M. (1919), 'Politics as vocation', in T. Waters and D. Waters (eds., 2015), Weber's Rationalism and Modern Society: New Translations on Politics, Bureaucracy, and Social Stratification, New York: Palgrave Macmillan, pp. 129-198.

Williamson, O. E. (2000), 'The New Institutional Economics: Taking Stock, Looking Ahead', Journal of Economic Literature, 38(3): 595-613.

Cite this article: Gutmann J, Voigt S (2022). Testing Todd: family types and development. Journal of Institutional Economics 18, 101-118. https://doi.org/10.1017/S1744137421000175 